FACTA UNIVERSITATIS

Series: Law and Politics Vol. 18, Nº 3, 2020, pp. 197-206

https://doi.org/10.22190/FULP2003197D

Scientific Review Paper

\title{
ABOUT THE IMPORTANCE OF STUDYING (EUROPEAN) MONETARY LAW AT DOMESTIC LAW FACULTIES *
}

\author{
UDC 336.7 \\ $339.72 / .73$ \\ 378.016
}

\section{Marko Dimitrijević, Srdjan Golubović}

Faculty of Philosophy, University of Niš, Serbia

\begin{abstract}
This paper points to the real and logical need for academic studying of the positive law discipline of (European) Monetary law at Law Faculties in Serbia. This branch of law is necessary for the optimal legal regulation of monetary policy, state monetary conduct and preserving monetary stability as an important public good for every monetary jurisdiction in the world. The introduction of Jean Monnet Module for European Monetary Law at the Faculty of the Law, University of Niš, is a very important step in academic teaching and scientific research on the legal regulation of public monetary affairs. The authors conclude that lawyers must have specialist knowledge from this branch of law, considering the frequency of monetary disputes and implication of monetary stability on living standards of monetary habitats and their rights to have healthy and solid currency.
\end{abstract}

Key words: Jean Monnet Module for European Monetary Law, monetary jurisdiction, lex monetae, state monetary conduct

\section{INTRODUCTION}

If we carefully look at events in international monetary relations in the last decade, we can notice a new wave of European monetary law. It has been more affluent, more intense, and more complex than all the previous events on the global monetary scene. New tendencies are not only reflected in the primacy of soft law over primary monetary sources,

Received October $17^{\text {th }} 2020 /$ Accepted November $12^{\text {th }} 2020$

Corresponding author: Marko Dimitrijević, LL.D., Assistant Professor, Faculty of Law, University in Niš, Trg Kralja Aleksandra 11, 18000 Niš, Serbia.E-mail:: markod1985@prafak.ni.ac.rs

Srđan Golubović, LL.D., Full Professor, Faculty of Law, University in Niš, Trg Kralja Aleksandra 11, 18000 Niš, Serbia. E-mail:: golub@prafak.ni.ac.rs

* This paper is prepared within the project program "Jean Monnet Module for European Monetary Law" (project number: 620002-EPP-1-2020-1 RS-EPPJMO-MODULE) co-funded by the Erasmus+ Program of the European Union.

The European Commission support for the production of this publication does not constitute an endorsement of the contents which reflects the views only of the authors, and the Commission cannot be held responsible for any use which may be made of the information contained therein." 
new jurisdictions of international judicial instances for resolving monetary and fiscal disputes, new central bank powers and the evolution of the concept of monetary sovereignty, but also in making more "human approaches" in the implementation of monetary law prerogatives by leading international organizations.

EU monetary law as a positive branch of law is understood as a set of legal rules which determine a monetary unit for the denominated amount of public debt. The authors believe that the justification (ratio legis) of scientific, empirical, and social research on European Monetary Law at the Faculty of Law in Nis and in the field of contemporary Serbian legal science is based on the main hypothesis that this area of law has a significant impact on the broadly established field of Serbian long-term economic policy goal as well as on Serbia's EU integration process. It also has an important effect on human rights because it determines all segments of the living (economic) standard and general life quality of citizens who live in the territory under specific monetary jurisdiction. For this reason, Serbian legal science must focus on identifying causal and consequential connections between postulates, institutes and subjects of national and supra-national international monetary relations in the European Union, as well as on the transmission and their feed-back mechanisms in the field of social and economic rights where that influence is most pronounced.

\section{EUROPEAN MONETARY LAW AS A POSITIVE BRANCH OF LAW}

Legal regulation of monetary relations is a conditio sine qua non for maintaining monetary stability, both at the national and the international level. In the context of globalized capital flows, the effects of monetary instability are characterized by undermining of the authority of monetary jurisdiction, the collapse of the monetary system, and the relativization of monetary (state) management functions. These effects are not territorially limited only to the territory subject to the operation of specific monetary legislation but also to other countries that are connected with the affected one in geographical terms or act as their foreign trade partners. The reason for the this (negative) spillover of monetary instability lies in the fact that all monetary jurisdictions inevitably participate (either directly or indirectly with varying degrees of intensity) in the creation of an international monetary order, whose fundamental principle is to preserve the monetary balance as the basic component and the precondition of general economic stability (Dimitrijević, 2019: 286).

The contribution of states in the implementation of this fundamental principle in practice can differ from one country to another, depending on the developed degree of monetary consciousness, as well as the solutions enacted in positive monetary legislation, which must be regulated by special monetary laws (outside the private civil law branch, which was a common trend in the period when monetary integration was not so prominent). Monetary legislations in different countries represent sui generis legal sources, where the object of social protection (as a specific legal situation) is determined by the need for optimal regulation, management, and protection of relations between participating monetary agents (public entities).

The specificity of monetary law norms is conditioned, inter alia, by the sophisticated competence of monetary institutions that participate in their creation and implementation. At the national level of monetary management, these are central banks, supreme audit institutions (organized as judicial or administrative), public debt management agencies, and other monetary policy actors who participate as interveners in monetary procedures. At the international level, 
the primary entities are the International Monetary Fund (IMF) and the European Central Bank (ECB), whose jurisdiction ratione materiae is not only to apply the existing monetary norms but also to create their law that exists within the international monetary legal corps relatively independently of supranational law. This is confirmed by the fact that refers to the process of international monetary law disintegration that has reached a high level of development, sufficient to enable the start of the disintegration process. Thus, nowadays, we can talk about the Law of the IMF and Law of the ECB.

The process of evolution of European monetary law, and in particular its key institutions such as monetary sovereignty, best illustrates the need for profound academic research in this field of law in domestic curricula. Namely, in the conditions of debt crisis, Member States have become especially aware of the significance of the legal concept of economic (monetary) policy co-ordination for the normative and economic efficiency of monetary solutions. Also, due to their rigidity and difficult process of a roll-over, the primary sources of monetary law became a kind of a relic of traditional economic integration and, therefore, had to be supplemented by provisions of secondary legislation embodied in new institutional models of economic governance, such as the European Semester, the European Stability Mechanism and the Fiscal Agreement that initiated monetary and fiscal disputes before the European Court of Justice. The Court decisions in fiscal disputes (related to the application of fiscal rules) and monetary disputes (in which the European Central Bank's active and passive procedural legitimacy was fully realized) pointed to the urgent need to educate judges, advocates, and lawyers for the purpose of acquiring specialized knowledge in the field of monetary law. The role of soft law in optimal regulation of monetary relations is crucial because it balances between extremely dynamic monetary events that require the intervention of public authorities, on the one hand, and insufficiently adaptable primary monetary legal sources whose slow adaptation (reform) potentially threatens to deepen the external time-lag in fulfilling desired results, on the other hand. This does not mean that secondary legal sources conflict with the primary one, since we must not forget that the primary legal projections are conditio sine qua non for determining the monetary order in dimensions of its legitimacy and legitimacy. In certain circumstances, the hybrid character of monetary law can also give major importance to the precedents presented in secondary legislation (for example, the nobailout clause for public debt that is relativized in practice).

Certainly, these remarks are not meant to expose the imperfection of monetary norms; in our opinion, it only confirms the "life" of this branch of law, which does not pretend to be perfect in its nomotechnics, but surely far from real events in the economic sphere of social life. As monetary law stands in a close synthetic and dialectical relationship with monetary finance as an economic discipline, it is not so surprising that in some cases secondary legal sources protect the economic stability against the legal stability. Moreover, the question that arises here is whether the implementation of monetary norms at the moment of crisis relativizes the distinction between legal and economic security so that, instead of being perceived as separate (opposing) levels, they are observed through the same social value, which again speaks of its sophisticated nature that goes beyond all limitations of others types of legal norms that cannot withstand a "test" of global economic and political earthquakes.

Creating conditions for a more robust functioning of the European Court of Auditors in controlling the work of the European Central Bank (which can contribute to the more responsible implementation of a single monetary strategy, its evaluation and identification of those actions of monetary agents that can destabilize the strategy to a lesser or greater 
extent) is also very important for laying a solid foundation for further development of European Monetary Law. In this context, we believe that there is a real and logical need for future lawyers to study the discipline of international monetary rights. It can be achieved by incorporating and developing special syllabuses in undergraduate and postgraduate law studies. By ensuring timely acquaintance with the content of monetary relations, monetary disputes can be avoided or solved in a way that will not be accompanied by unnecessary sensationalism and bad reputation, including both the monetary disputants and the judicial or arbitration instance that tackles such disputes and contributes to the clarification of monetary facts in a way that does not cause doubt in the parties' motives.

In considering the subject matter of EU Monetary law, we must take into account the fact that it has evolved from national monetary law, which has long been studied almost exclusively in the domain of private (civil) law because monetary obligations are a very widespread element of different types of freight contracts. We consider that this approach in defining the national monetary law is rather unilateral and, as such, leaves space for numerous legal gaps, which can partly explain the unsatisfactory legal arguments of the courts in resolving monetary disputes. Namely, we consider that the monetary norm is conceived as a special form of a legal norm that governs social relations with the monetary element in the broadest sense of the word. In terms of its nature, the monetary norm is very similar to the tax norm, which means that it regulates concrete legal-economic fact (here monetary). Notably, this hybrid factual situation is not solely determined by legal facts but also by the economic facts. Consequently, in the legal definition of money, it is quite clear that we must also respect the functions of money as an economic category defined in the broadest sense. Although the international monetary order of the 1970s and 1980s was not developed as it is today, we think that the concept of monetary sovereignty had to be considered within the framework of the international order, in the manner of its manifestation, the conditions and obstacles for exercising the state monetary prerogatives outside the territory of the domestic monetary jurisdiction. In these reflections, we can notice the norms of the classical international monetary law which has been theoretically shaped later.

Arthur Nussbaum, the prominent monetary law theorist, was the first who spoke about this tendency in his capital work titled "Money in the Law" (1939). It was the first academically shaped thought on the science of monetary law (without being observed under the auspices of an obligation law). ${ }^{1}$ Considering the modus operandi of monetary sovereignty, Nussbaum notes that international monetary law cannot be clearly "brought under the scope of international private law, nor the scope of international public law", as it is a hybrid branch of law (Nussbaum, 1939: 1-2). We can note that this work was written in the period before the extensive globalization of international financial flows but, today, it is clear that International and European monetary law is far closer to the branch of public law because the main entities in international monetary relations are specialized international economic and financial organizations, such as: the International Monetary Fund, the World Bank, the Bank for International Settlements, and the European Central Bank.

The actuality of monetary law stems from the fact that solving the various effects of monetary problems produces direct consequences on the rights and obligations of the subjects involved in monetary relations. Practitioners are particularly concerned about this

\footnotetext{
${ }^{1}$ Although this work was written in the first half of the $20^{\text {th }}$ century, the author's argument was, in our opinion, far removed from the time. Being the first comprehensive theory on monetary law, it is "pioneering" in a sense that it includes benchmark standards which are still used by modern theoreticians of monetary law today.
} 
issue, primarily lawyers who cannot give a precise answer to the question of the legal profession's attitude towards changes in the law of value; hence, their answers are usually superficial and incomplete. Moreover, many monetary problems that emerged through history could not be solved at a given time, and their intertemporal transmission was at the expense of the future generations. For instance, some problems that escalated during earlier monetary crises are still current, such as: the consequences of hyperinflations, oil crises, and the collapse of the domestic monetary system (Hirschberg, 1981: 92-93).

In essence, monetary law is the legal science response to changes accompanying the law of values when the scope of legal rules in the monetary sphere is sustainable. In the circumstances where the law of values appears to be rather unstable in all world economies, there is no dispute that monetary law must be treated as a branch of modern (positive) jurisprudence. According to Hirschberg, monetary law is embedded in the very foundations of the overall legal architecture. Even in circumstances where the law of values remains unchanged in space and time, it would not concurrently imply the need to abolish monetary law; it would only point to its undeniable theoretical significance, while the practical significance is reduced. However, this author states that the law of values is never likely to be stable, although there have been periods in history when the law was characterized by a relative degree of stability (inter alia, from the second half of the $19^{\text {th }}$ century in Europe, with the introduction of the gold standard, its instability almost got the traits of the rule, not an exception). The monetary problems of pre-war and post-war states are very different in terms of their causes and consequences; however, what appears to be a universal problem in all monetary jurisdictions in the world is inflation. Hirschberg emphasizes that international monetary problems, which are reflected on the national monetary law, differ from each other only in the degree of manifestation, and not in their type, which we must bear in mind when analyzing the institutions of European monetary law. Its extraterritoriality cannot be ignored and, for that reason, the legislator must transform the existing subject matter of national monetary law by ensuring full observance of this fact. The monetary problems can no longer be treated as temporary, and the law of value can no longer be perceived as the expected regularity that always occurs after the flow of the transitional period. At this point, we must point out the fact that the law of values is economic regularity (not a social relationship regulated by a legal norm), which, in our opinion, was the main problem of unsatisfactory results in applying the rules of early monetary law (Hirschberg, 1976: 226-227).

The lack of the legislator's understanding (in terms of identifying economic legality with legal regularities) has complicated the development and application of monetary law at an early stage of its implementation. In the circumstances when the legislator was passive in ensuring the adequate regulation of monetary law, the only possible form of reform was the "bottom-up" reform, which is generated by the citizens living in the specific monetary jurisdiction. Such examples were particularly characteristic for Great Britain, where the so-called "stop and go policy" initiative produced good results in the fight against inflation. The purpose of this initiative was to introduce citizens with the responsibility of the state in solving monetary problems, promote their understanding of the inflation phenomenon and raise awareness about the consequences for their everyday life (Hirschberg, 1976: 226).

Therefore, more than ever before in monetary history, there is a need to increase the number of institutes and specialized associations dealing with the problems of monetary law. In particular, there is a need for a greater degree of involvement of the academic community, which has to show a far higher degree of interest because national and international monetary law in the inflation period represents effective legal defense against 
the harmful consequences of economic crises. Moreover, it sometimes seems that positive monetary law has been given a strategic position in determining the causes of inflation and providing resistance to inflation; yet, in its current form, it does not provide sufficient contribution to society in solving and controlling current economic problems. Therefore, one has to bear in mind that the work on the development of monetary law must be an ongoing process because it reflects the additional dimension of the problem of financing economic development and the achievement of full employment, i.e. the financing of social and economic progress; for this reason, it should not be treated as an autochthonous field of law.

\section{ClassificAtion, SOURCES, AND PRINCIPLES OF EUROPEAN MONETARY LAW}

We think that European monetary law can be defined as the entirety of legal norms governing the method of exercising and providing judicial protection to state monetary prerogatives in the EU area understood in a broadest sense. From this approach, more precise definitions can be derived, which, conditionally, would lead to making a distinction between the subjects of the process and material international monetary law. The procedural international monetary law would imply the entirety of legal norms that determine the establishment, operation, and competence of international monetary institutions (such as the $E C B$ ), while the substantive international monetary law regulates the content of public monetary relations with an element of extraterritoriality (public debt management and providing financial assistance). In the circumstances of monetary integration, this classification remains relative since the creators of monetary unions must concurrently pay attention to both substantive and procedural norms, which must be mutually harmonized to the maximum. This consistency is indispensable because the material dimension always crosses the formal one when constituting the pillars of future monetary unions and strengthening the existing ones.

Based on the aforementioned classification, we can determine primary and secondary sources of European monetary law. Primary sources are embodied in the so-called "founding treaties" (the Treaty of Maastricht, Amsterdam, Nice, and Lisbon), as well as in the provisions of the national monetary legislation regulating the establishment and work of central banks and the area of public debt management. Secondary sources are embodied in the so-called soft law, which is elaborated in the secondary legislation, such as the statutes on the work of central banks and the strategy of public debt management. Sui generis intergovernmental agreements in the domain of new models of macroeconomic management in the Eurozone (the Agreement on the European Stabilization Mechanism, and the Agreement on Coordination, Governance, and Stabilization in the Economic Monetary Union, i.e. the Fiscal Agreement) have a special place among the secondary sources. Their legal nature was the subject matter of consideration by the constitutional courts of the Member States and, later on, by the European Court of Justice (due to non-compliance with the provisions of primary legislation in the sphere of centralized monetary policy). For these secondary sources of international monetary law, it is characteristic that they were created as an EU institutional response to the consequences of the global financial crisis; so, their ratio is the protection of economic stability, rather than legal certainty, which is an atypical situation; however, due to the development of events, it was a necessary response aimed at evading a fiscal moratorium.

We must not forget that secondary sources are extremely important in international monetary law because they fill in legal gaps in the existing provisions of primary law and more precisely regulate the conditions for implementing the monetary norm. Given that the 
process of amending the law (and especially international agreements) is rather complicated and burdened with technocratic demands, rigid laws cannot follow the dynamics of monetary relations; thus, the flexibility of soft law is its advantage in the new economic circumstances that the legislator could not foresee when designing primary legislation. For this reason, we can see the practical importance of economic education of lawyers, who must be familiar with the basic principles of macroeconomic models used by economists. Moreover, in case of monetary legal regulations, we may be in a position to determine the economic effects of the application of specific legal norms; namely, in addition to normative efficiency, a good law must also satisfy the requirement of economic efficiency, which is essential for the optimal regulation of a country's economic system.

The basic principle of monetary law is the principle of lex monetae which implies that entities that conclude a public loan contract are generally free to choose the currency in which they will be denominated, but once they make this choice no later decisions of the issuing State can affect its validity. This means that replacing the existing currency with a new one (which may be designated in some countries during the period of hyperinflation to avoid a complete collapse of the monetary system) does not affect the nature and duration of the contractual monetary obligation (Wahlig, 2000: 122-123). The monetary literature states that this principle implies not only the designation of a currency unit but also determining its subunits as well as specific items that have the status of a legal tender. In the event of a change in the currency unit, the validity of the principle is particularly important for the protection of the interest of the creditor of the public loan, but also of the borrower, since such conversions in the event of his withdrawal can have serious legal and economic consequences (Dimitrijević, 2018: 44).

The application of the principle follows the perception of civil law that monetary obligations are indestructible, even in case of termination of the currency in which the contract is concluded. This fact is best illustrated by the centralization of monetary policy at the communitarian level and the financial supervision that is still carried out by the national central banks. The controversy arising from this plan is that the lex monetae has been transferred to the level of the EU. These conceptions are confirmed by the fact that all Member States retained a certain degree of influence on the monetary policy that is best reflected in the exercise of the voting rights of the governors of the national central bank in the Board of Directors of the ECB. The great challenge in determining the monetary sovereignty in the EMU is to measure the level of remaining national monetary sovereignty and set the boundaries among the members because it is hard to determine where the sovereignty of one Member State ends and where the monetary sovereignty of another Member State begins. The evolution of lex monetae is evident in the example of the European banking union which represents a centralization of banking policy under the role of the European Council. ${ }^{2}$

The most significant changes in the manner of exercising monetary sovereignty are reflected in the circumstances of monetary integration when the states approach monetary unions. Monetary integration per se does not mean the loss of monetary sovereignty, but rather its adjustment in the circumstances of coordination of national monetary policies, for the purpose of attaining certain benefits, even though practice shows that globalized

\footnotetext{
${ }^{2}$ The structure of the Banking Union is based on three pillars: Single Supervisory Mechanism, Single Resolution Mechanism, and related financing mechanisms such as Common Deposit Guarantee Fund, the Single Occurrence Deposit Insurance Scheme, and the Common Security Mechanism.
} 
economic systems are governed by the following rule: the smaller the state, the lesser the intensity of its monetary sovereignty (Angyal, 2009: 110). Many monetarists consider that, upon the completion of the third phase in the formation of the EMU, Member States were only exposed to theoretical loss rather than the actual loss.

These conceptions are confirmed by the fact that all Member States retained a certain degree of influence on the monetary policy, which is best reflected in the exercise of the voting rights of the governors of the national central bank in the Board of Directors of the ECB. Notably, in addition to being members of the IMF, member states may form special regional unions. Their membership in regional unions may also relativize their sovereign monetary powers to a lesser or greater extent, which can best be seen in the EMU case (Golubović, 2010: 22).

The great challenge in determining the monetary sovereignty in monetary unions is to measure the level of remaining monetary sovereignty and set the boundaries among the members because it is hard to determine where the sovereignty of a Member State ends and where the monetary sovereignty of another Member State begins. The state, as the holder of monetary sovereignty, primarily enjoys three exclusive legal powers: the right to define the domestic currency (and impose criminal sanctions for direct or indirect expulsion of the domestic currency from the market - lex condenate monetae), the right to determine and change the value of the domestic currency (and amend the institutional regulation of the domestic banking system), and the right to use domestic or any other currency in monetary and legal relations within its territory (Proctor, 2005: 122). Monetary conduct, (viewed in a wider context), refers to how monetary sovereignty is implemented in practice (for example, establishing a fixed or fluctuating exchange rate, imposing foreign exchange controls in regulating monetary relations with other countries).

\section{JEAN MONNET MODULE FOR EUROPEAN MONETARY LAW AT THE FACULTY OF LAW, UNIVERSITY OF NIŠ}

In September 2020, the Faculty of Law at the University of Niš was awarded a three-year project within the Erasmus + Jean Monnet program of the European Union to organize teaching and scientific research in the field of European monetary law. This project is a very important step in introducing the discipline of Monetary Law as an independent course at Serbian law faculties. The "Jean Monnet Module for European Monetary Law" has been envisaged within the undergraduate (bachelor academic) law study program, but this module may also be enrolled by students of master and doctoral degree law study programs, as well as by legal practitioners (the judiciary, lawyers, public authorities). Within the framework of the Jean Monnet Module, students will study the issue of normative and economic efficiency of fiscal rules in the European Union and their impact on domestic monetary legislation, as well as the law of the European Central Bank which has been identified (in conditions of globalization of economic and monetary flows) as a distinctive part of the general monetary law and recognized as an independent scientific discipline.

For the first time, students will have the opportunity to get acquainted with the characteristics and outcomes of monetary disputes involving the full implementation of active and passive procedural legitimacy of European monetary agents and the monetary jurisdiction of the European Court of Justice, as well as the application of legal mechanisms of European economic governance in the European Union (i.e. interstate agreements aimed at 
ensuring legal and economic stability in the EMU). The courses will be attended by undergraduate, graduate and postgraduate law students, as well as by legal professionals.

Upon completion of the Jean Monnet module, course participants will successfully master and be able to: 1) monitor, critically research and analyze both traditional and contemporary trends in the legal regulation of EU monetary flows and policy; 2) competently, scientifically, and argumentatively discuss, research and present the results of their scientific work that will contribute to the development of scientific thought in the field of studying EU monetary law; 3) work on research, organization and optimal monetary management, monetary advisory and similar activities that are covered by the content of the Jean Monnet module. In the future, in conjunction with the appropriate knowledge from other subjects, course participants will be able to work on signing and implementation of international agreements and documents in the field of European monetary law and participate in the work of international monetary institutions.

In general, the outcome refers to promoting the understanding of the subject matter by exchanging attitudes, ideas, experiences, providing valuable knowledge input in solving complex legal issues, improving the research methodology, and more precisely determining the direction and scope of future research, which should ultimately contribute to providing the optimal solutions for open legal issues and solving the problem of monetary legal gaps that require a coordinated response from the academia at the international level. In particular, the student is expected: to understand the process, structure, and mechanisms of managing international monetary-law relations; to acquire general and special knowledge about the advantages and disadvantages of existing legal solutions in the field of primary and secondary monetary legislation in the EU; to become acquainted with the hybrid nature of the Institute of European monetary law; to master the appropriate legal regulations and to recognize the connection between European monetary law and European and international economic (investment) and international financial law; to master the key terms, concepts, and categories in the field of public monetary management of the state and international monetary organizations, and to develop the ability to apply the acquired knowledge in selecting an optimal monetary solution for resolving a specific factual situation in Serbian monetary legislation.

\section{CONCLUSION}

In the last decades, we can observe that the sources of monetary law may increasingly be found in some new legal and economic facts which were formed by international monetary agents when concluding certain interstate agreements in the domain of secondary legislation. In conditions of the global economic and financial crisis, these interstate agreements perform the function of filling in legal gaps in the primary sources of international monetary law. The basic aim of studying European Monetary Law as an indipenedent course is to develop scientific knowledge, academic and practical skills in consideration of new tendencies in the development of monetary law of European Union in the contemporary economic, legal, political and business environment, and to train students to understand the nature and importance of optimal public monetary management in light of appropriate legal regulations and economic dimensions in the contemporary market economy system. Upon the completion of the course, students will master and be able to apply relevant methods and procedures for assessing the impact of various factors that determine the development and structure of monetary sovereignty in globalized financial relations, the law of the European Central 
Bank, the monetary jurisdiction of national and supranational courts, legal rules in resolving monetary disputes as sui generis types of administrative disputes, and the implications of monetary and legal relations on the protection of human rights. They will also acquire specific skills needed for future career in various monetary institutions, particularly bearing in mind that this is a field of law which is not sufficiently represented in the contemporary legal theory and empirical jurisprudence. The EU Monetary law course also has a practical dimension, given the fact that the Republic of Serbia opened Chapter XVII titled "Economic and Monetary Policy Coordination" on its path to EU integration.

\section{REFERENCES}

Angyal, Z. (2009). Monetary Sovereignty and the European Economic and Monetary Union. European Integration Studies, Miskolc, Vol. 7 (1), 2009, pp. 109-119.

Christoph, H.; Dornacher, D. (2017). European and International Monetary Law: An Introduction. Munich: Springer.

Dimitrijević, M. (2018). Institucije medjunarodnog monetarnog prava (International Monetary Law Institutions). Niš: Centar za publikacije.

Dimitrijević, M. (2019). The Evolving Concept of Lex Monetae in European and International Monetary Law. Foreign Legal Life 4, 286-321.

Golubović, S. (2010). Fiscal Rules in European Monetary Union, Niš: Centar za publikacije.

Hirschberg, E. (1976). Monetary Law and Monetary Crises. Comparative \& International Law Journal of Social Affairs 9, 226-227.

Hirschberg, E. (1981). Contemporary Monetary Problems and Their Legal Effects. Acta Juridica, 92-93.

Lastra, Rosa Maria (2015). International Monetary and Financial Law, Oxford University Press, New York.

Nussbaum, A. (1939). Money in the Law. Columbia Council for Research in Social Sciences, The Foundation Press Inc, Chicago.

Proctor, C. (2005). Mann on the Legal Aspects of Money. Oxford University Press.

Wahlig, B. (2000). European Monetary Law: The Transition to the Euro and the Scope of Lex Monetae, in: International Monetary Law: Issues for the New Millenium (ed. Mario Giovanoli), Oxford 2000, pp. 122-123.

\section{O ZNAČAJU IZUČAVANJA EVROPSKOG MONETARNOG PRAVA NA DOMAĆIM PRAVNIM FAKULTETIMA}

Predmet analize u radu jeste ukazivanje na stvarnu i logičku potrebu akademskog proučavanja pozitivne pravne discipline (Evropskog) monetarnog prava na pravnim fakultetima u Srbiji s obzirom na činjenicu da je ova grana prava neophodna za optimalno pravno uređenje monetarne politike, javno monetarno upravljanje i očuvanje monetarne stabilnosti kao važnog javnog dobra za svaku monetarnu jurisdikciju u svetu. Uvođenje Žan Mone modula za Evropsko monetarno pravo na Pravnom fakultetu Univerzieta u Nišu predstavlja vrlo važan korak u akademskom i naučnom pozicioniranju problematike monetarnog prava na silabusima osnovnih, master i doktorskih akademskih studija prava. Autori smatraju da pravnici moraju imati posebna znanja iz ove hibridne grane prava uzimajući u obzir učestalost monetarnih sporova i implikacije monetarne stabilnosti na životni standard monetarnih korisnika i njihova prava na zdravu i čvrstu valutu.

Ključne reči: Žan Mone modul za Evropsko monetarno pravo, monetarna jurisdikcija, lex monetae, monetarno upravljanje 